\title{
Indigenous Environmental Knowledge of Borana Pastoralists
}

\author{
Dejene Alemayehu*1, Zerihun Doda ${ }^{2}$ \\ ${ }^{1}$ Borana Zone Culture and Tourism Office, Yabello, Oromia, Ethiopia \\ ${ }^{2}$ Centre for Research in Ethics and Integrity, Ethiopian Civil Service University, Addis Ababa, Ethiopia \\ *Corresponding author: dejenea987@gmail.com
}

How to cite this paper: Alemayehu, D. and Doda, Z. (2020). Indigenous Environmental Knowledge of Borana Pastoralists. Grassroots Journal of Natural Resources, 3(4): 110-131. Doi: https://doi.org/10.33002/nr2581.6853.03047

Received: 09 October 2020

Reviewed: 26 October 2020

Provisionally Accepted: 31 October 2020

Revised: 19 November 2020

Finally Accepted: 29 November 2020

Published: 20 December 2020

Copyright $\odot 2020$ by author(s)

This work is licensed under the Creative Commons Attribution International License (CC BY 4.0).

http://creativecommons.org/licenses/by/4.0/
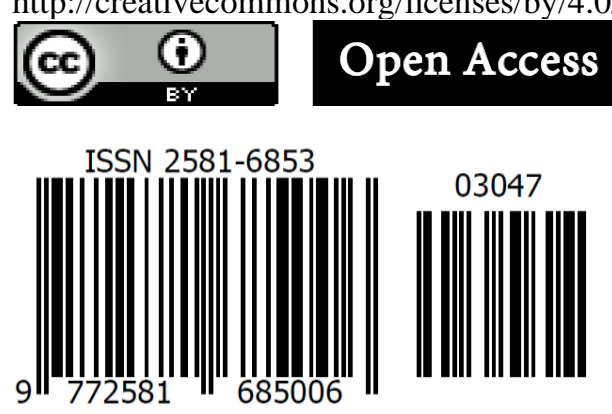

\section{Abstract}

This paper investigated the indigenous environmental knowledge (IEK) of Borana pastoralists in Dhas district of Borana zone in Southern Ethiopia. To select participants for key informant interview and focus group discussion (FGD), snowball sampling was used to pinpoint people who have IEK of Borana pastoralists. Results show that the customary practices of Borana pastoralists that linked to multi-dimensional natural resources management (NRM) include the taxonomy of pastureland and water resources instituted on the season of utility and gazing dimensions, range scouts, herd splitting, cattle mobility, herd diversification, and bush burning. However, currently owing to various factors the IEKs of Borana pastoralists have been facing threatening challenges that question their existence. The study incorporated the capitalization on the customary institutions that advance the IEK and cattle productivity finally improving the livelihoods of the Borana pastoralists. This research intends to help various stakeholders, predominantly pastoralist development office, ecologists and other development partners in a bid to develop Borana pastoralists, to boost their sustainability, and to promote sustainable NRM.

\section{Keywords}

Borana pastoralists; Indigenous environmental knowledge; Customary institutions 


\section{Introduction}

The Borana pastoralists are an Indigenous people ${ }^{1}$ who inhabit the southern lowland of Ethiopia. The Borana pastoralists have been living in the area since the $13^{\text {th }}$ century (Oba and Kotile, 2001, cited in Dalle, Johannes and Brigitte, 2006, p.1) and they are part of the larger Oromo speaking people of Ethiopia (Denge, 2011). The Borana pastoralists have developed varied and multifaceted systems of IEK (Boku and Irwin, 2003; Homann, 2004; Dalle, Johannes and Brigitte, 2006). Douglas (2002) defined IEK as "the complex ... assortment of knowledges, practices and representations that guided human societies in their countless interactions with the natural environment." According to Mehdi et al. (2013), IEK has played a key role in the economic and cultural development of humankind for millennia. There are nowadays innumerable Indigenous community preserved areas in many parts of the world, comprising hallowed forests, swamplands, landscapes, migration terrains, catchment forests, river and coastal stretches and nautical areas (Arjjumend et al., 2018). It is documented that official protected areas have often failed, whereas community's conserved areas show a success; hitherto they are often poorly recognized by State policies (Arjjumend and Beaulieu-Boon, 2018). Zerihun (2005) considered that the prime reason behind the failures of numerous conservation projects that supposedly aim to benefit Indigenous people is the underestimation of the IEK.

Hence, the IEK has faced upsetting challenges in the pastoralist's lowland territories of Ethiopia. It is observed that external interventions, originally planned and implemented to bring development and to improve the living conditions of the pastoralists, have disturbed IEK base and weakened its applications in daily life of pastoralists (Dalle, 2004, cited in Dalle, Johannes and Brigitte, 2006). Ayalew (2004) argued that appreciation of the indigenous ways of NRM have created sound effects on the productivity and sustainability of natural environment. The pastoralists are forced to restrict their traditional herding lifestyles and to concentrate with their large size of livestock in a confined area, causing further depletion of natural resource. Over the last three decades the IEK of Borana pastoralists has experienced severe forms of external invasions (Helland, 2006). Moreover, there has been a deliberate infringement of IEK of Borana people, as Ellen, Peter and Alan (2005) conferred, by virtue of several generations of top-down development interventions involving NRM in the pastoralist areas. Because of general social and political marginalization of pastoralists in Ethiopia, IEK has received scanty attention in public policy (Helland, 2006). The customary NRM were disregarded, and agrarians were encouraged to acquire sizeable territory of the pastoralists.

In sum, in semi-arid lowlands of Ethiopia especially in Dhas district of Borana zone, the IEK of Borana pastoralists has not been given noteworthy consideration. Dhas district is one of the pastoralist districts existing in the eastern parts of Borana zone. Dhas district is facing challenges of recurrent conflict, drought, invasion of thorny bush, environmental degradation, declining of grazing assets, weakening of customary rules, and ban on bush burning. Despite numerous studies

\footnotetext{
1 There is no usually agreed comprehensive definition of the Indigenous people, some accord on what constitutes Indigenous people have received some form of concord amongst human rights organizations. For instance, ILO Treaty 169 (1989) defines Indigenous peoples as: "Peoples in independent countries who are regarded as Indigenous on account of their descent from the populations which inhabited the country, or a geographical region to which the country belongs, at the time of conquest or colonization or the establishment of present state boundaries and who, irrespective of their legal status, retain some or all of their own social, economic, cultural and political institutions" (Article 1.1, p.7).
} 
conducted previously on the IEK of Borana pastoralists (e.g., Homann, 2004; Belayneh, 2016; Abdu and Robinson, 2017), the decisive customary institutions of rangeland and water resource management are not noticed adequately by the scholars. Therefore, this work extensively investigated the IEK of Borana pastoralists and proposes the pivotal role of customary institutions in sustaining the NRM processes. Present article focuses on the role of IEK in NRM, the practice of Indigenous knowledge based NRM and utilization strategies, the perceptions of local communities on NRM, the role of social capital in NRM and, finally, the challenges faced by the IEK of Borana pastoralists.

\section{Materials and Methods}

\section{Study Area}

This study was conducted in Dhas district of Borana zone administration in Oromia national regional state of southern Ethiopia. Dhas district is divided in to 7 pastoral associations (PAs) (Borbor, Tesso-kalo, Gayo, Mata-arba, Raro, Dhaas and Gorille). It is situated at $730 \mathrm{~km}$ south of Addis Ababa and $171 \mathrm{~km}$ from Yabello town, capital of Borana zone. The district is situated between $3^{\circ} 35$ and $5^{\circ} 37^{\prime}$ north latitude and $3^{\circ} 42^{\prime}$ and $30^{\circ} 30^{\prime}$ east longitude in the southern part of Ethiopia. It is bordered by Wacile, Miyo, Dire district and Dubluk, Guchi district and Somali regional state of Ethiopia in the north, west, southwest, southeast and east, respectively (Figure 1).

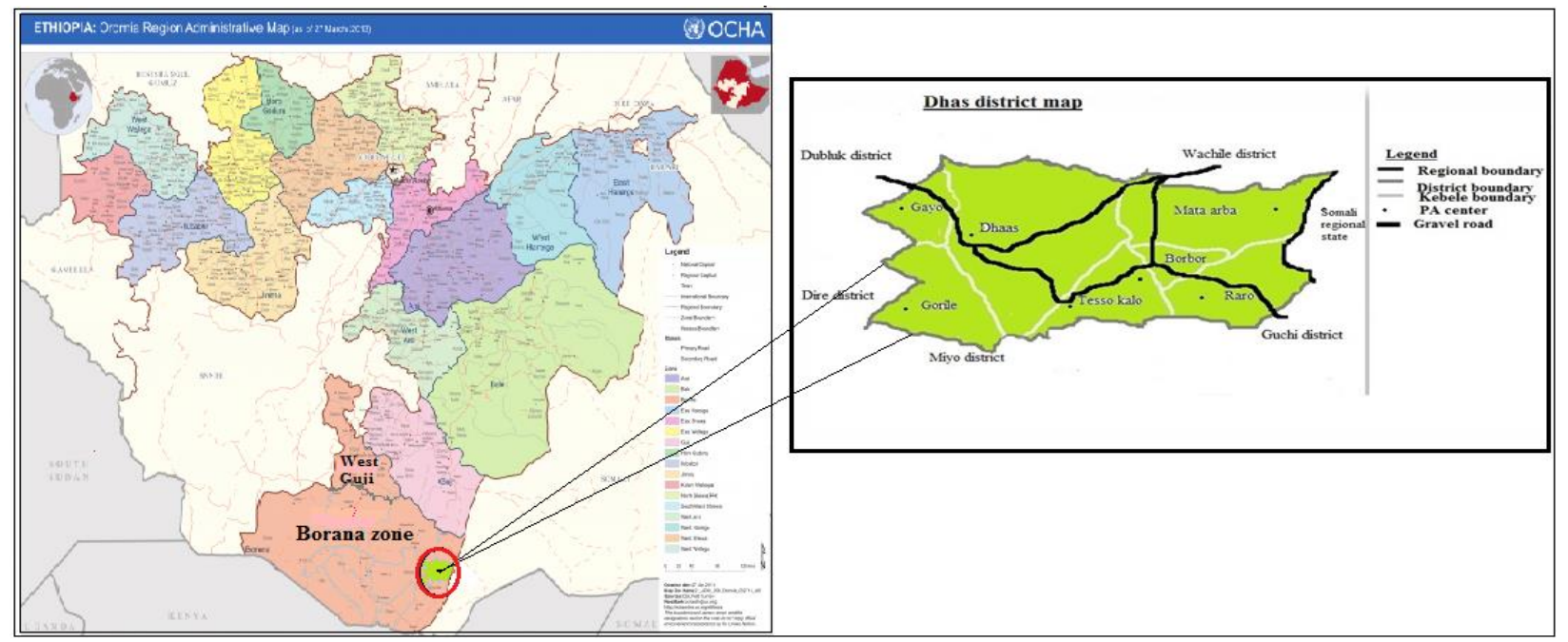

Figure 1: Map of study area [Source: Adapted from Dhas District Pastoralist Development Office (DDPDO, 2019)]

Dhas district has an area of $3447 \mathrm{~km}^{2}$ and a population of 59,831 of which 26,086 and 33,745 are males and females, respectively (DDPDO, 2019). Dhas district is the home to pastoral people rearing cattle, goats, sheep and camels. According to DDPDO (2019), land use description is revealed as follows: rangeland accounts for $47.3 \%$, bush land $44.37 \%$ and bare land $8.33 \%$. The altitudinal range varies from 1100 to 1450 meters above sea level. The mean annual rainfall is between $450 \mathrm{~mm}$ and $550 \mathrm{~mm}$ (DDPDO, 2019). 


\section{Data Collection}

Data collection was carried out in Dhas district from April 2 to May 18, 2019. Qualitative methods of data collection such as key informant interview, focus group discussion (FGD) and direct observation were used to explore the IEK of Borana pastoralists to build a complex holistic picture, to analyze narratives and reports, and to conduct the study in the natural setting of the participants. While selecting participants for key informant interview and FGD, snowball sampling was used. Snowball is a sampling technique used to identify cases of interests reported by people who know other people involved in analogous cases and have insights into the IEK of the Borana pastoralists (Bernard, 1995).

\section{Key Informant Interviews}

For the purpose of this study, key informant was selected by considering the structure of the society, government and the content of the inquiry. Accordingly, two key informants from Dhas district pastoralist development office were selected based on their direct concern with the communities under the investigation. In addition, all key informants from the community were selected based on their role within the community, experience and knowledge bases. Thus, seven key informant interviews were conducted with the customary leaders and elders who lived there and had potential insights on the IEK of Borana pastoralists. In total, 9 key informant interviews were conducted during the field work.

The customary NRM of Borana pastoralists was founded on distinctly gender division of labour with men and women having diverse roles, liabilities and decision-making authority. Within the Borana pastoralists even though women partake in the maintenance of rangeland and water resources, customary elders have more communal role where verdicts about the access and management of all water and rangeland resources are primarily made by them. Therefore, women informants were not selected in this study for key informant interviews and FGDs.

\section{Focus Group Discussion}

Mainly FGD was conducted to obtain in-depth information on the roles, practices, perceptions and insights of the groups on the IEK of Borana pastoralists. According to Mishra (2016) the optimum size for FGD should be six to eight participants per session. For this study, sample size for FGD was conditioned by two factors: the group must be small enough for everyone to participate and more manageable in contrast to larger group usually harder for moderator to control. Thus, seven FGDs were conducted involving customary leaders (ranging from 45 to 80 years of age). Each FGD included six male participants in all PAs who were selected in consultation with the PA administration.

\section{Direct Observation}

Direct observation helps to comprehend the setting from both insider and outsider perspectives. Hence, the purpose of observation was mainly to understand the general condition of the study area (to witness how Borana pastoralists manage their livestock, rangeland and water resources) and to re-track back the missing information from detailed interview questions. 


\section{Data Analysis}

The data gathered from different sources by employing key informant interviews, FGDs, direct observations and secondary sources were compiled in the ways that was easy to manage. Following the completion of data collection, the results of the analysis were interpreted and discussed by using qualitative approach. The method of analysis used under this study was a qualitative approach of thematic analysis. Thematic analysis is a method used for "identifying, analysing, and reporting themes within the data" (Braun and Clarke, 2006, p.79).

\section{Results}

\section{The Role of Indigenous Environmental Knowledge in Natural Resource Management}

The Borana pastoralists were endowed with customary management of rangeland and water resources in their localities. According to key informant and FGD participants, Borana pastoralists utilized their IEK to make a living, to know the unstable environmental condition, to assess the browsing capacity of rangeland, to sustainably manage meagre pastureland and water resources, etc. through their customary institutions of NRM.

Obviously, Borana pastoralists have developed a flexible IEK to take advantage of the volatile assortment of their dryland ecology. Thus, the knowledge of flora species and their significance, rotational bush scorching, herd diversification, herd splitting, the customary practice of water management and utilization strategies were some of the finest examples that display the fundamental roles of IEK of Borana pastoralists in sustaining the NRM. Accordingly, this environmentally comprehensive and adaptive traditional knowledge allowed Borana pastoralists to survive and acclimatize and manage their natural resources for generations. The study indicated that, in order to recuperate and strengthen the existing IEK of Borana pastoralists, it is advisable to cooperate with IEK and its customary institutions in every development aspect starting from the very beginning of project planning to implementation.

\section{The Practice of Indigenous Knowledge Based Natural Resource Management and Utilization Strategies}

Based on key informant and FGD participants' elucidations, this study identified the subsequent customary NRM and utilization strategies that have been practiced by Borana pastoralists to sustain their natural resources.

\section{Rangeland Management and Utilization Strategies}

\section{Rangeland taxonomy}

Banking upon customary institutional practice Borana pastoralists divided the entire rangeland into two main parts on the foundations of their functions and cyclical grazing dimensions called lafa warra guda (land for home-based livestock) and lafa gu'essa (land for non-lactating livestock). According to informants, land for lafa warra guda was supplementary divided into three segments based on their functions, namely lafa jabbi (land for calves), lafa hawicha (land for lactating cows) 
and lafa qubsuma (land for settlements). As they are yet pure pastoralists, farming was not practiced in Dhas district. By contrast, the Borana pastoralists that live in other districts of Borana zone have practiced trivial scale farming in the vicinity of lafa warra guda. As a result, in other districts of Borana zone, lafa warra guda was segmented into four divisions on the basis of their functions.

Among the Borana pastoralists the taxonomy of rangeland into lafa warra guda and lafa gu'essa was implemented through the accords between the customary leaders as well as community members who delegated from their respective geographical units. So, as to accomplish this, firstly jaarsaa reera (customary leaders for groups of adjacent encampment clusters) and community representative from each reera (groups of adjacent encampment clusters), were authorized to delimit gazing land between lafa warra guda and lafa gu'essa. Then on the second phase jaarsaa arda (customary leaders for groups of villages), abba olla (village head) and community members from arda (groups of villages) emanate together to delimit the perimeter of grazing land for hawicha (lactating cows), jabbi (calves) and qubsuma (settlements), respectively. In contrast, lafa gu'essa cannot be segmented into varied land utilities unlike lafa hawicha as the livestock that migrated to lafa gu'essa solely comprises pregnant cows, deterred calves and oxen.

\section{Abburu}

According to the Borana elders abburu (scouts) is the practice of sending skilful herder by customary leaders to conduct assessments on the rainfall and pasture availabilities to remote areas. Predominantly, assessments on water and pasture availability are piloted soon after the early rainy season of ganna (March to May) and hagayya (September to November) when rain commences or when drought season is extended to restrain the leverages of overgrazing in lafa warra guda. Therefore, the time and the number of livestock that proposed to migrate to assessed areas are typically based on the availability of pasture and water resources and other relevant figures acquired by the scouts. Additionally, scouts also assess the transitory satellite camp for nonlactating livestock that intended to migrate to scouted areas. Moreover, key informants itemized that:

"Prior to sending abburu squad to conduct assessments, customary elders [i.e., jaarsaa reera, jaarsaa arda and abba olla] discuss the places of assessments. After they agreed on the places of assessments, they let the scouts to conduct evaluations. Once the scouts return from assessments, customary elders query them by saying manin galtani (literally asking for the results of their assessments). If the scouts return with prolific assessment results, they reply to customary elders by saying godanan gale (we come back with mobility) ... after they thoroughly scrutinized the results of evaluations. The customary elders then recommend the exodus of non-lactating livestock to scouted areas. In the course of the drought time, they would settle near traditional deep wells; if not drought time, they would encamp in the areas where either small ponds or dololo (surface water) are accessible."

\section{Customary institutions of "jaarsaa dheeda", "jaarsaa reera", "jaarsaa arda” and "abba olla"}

The decisions for grazing management at dheed $a^{2}$ level on the bases of pasture and water resources availability was applied under the supervision of jaarsaa dheed $a^{3}$. The customary leader of jaarsaa dheeda was responsible for governing the grazing precincts across the Mata-wayama rangeland 
unit of Dhas district. Geographically, the entire Borana lands were divided into five dheedas namely Gomole rangeland unit, Golbo rangeland unit, Dire rangeland unit, Malbe rangeland unit and Mata-wayama rangeland unit (see Figure 2). Out of these five rangeland units, Mata-wayama rangeland unit encompassed Arero and Dhas districts of Borana zone administration; and all rangeland units have one jaarsaa dheeda in their respective rangeland unit ${ }^{2}$.

The verdict made by the customary leader of jaarsaa dheeda has considerable powers including the penalizing of convicts that despoiled the customary governance of pastureland. Thus, jaarsaa dheeda has the ultimate authority to make final verdicts on the issues related to collective pastureland management and configuration of cattle mobility across the Mata-wayama rangeland unit of Dhas district. Correspondingly, the tasks for handling rangeland at reera and arda levels were given to customary leaders of jaarsaa reera and jaarsaa arda, respectively. According to Borana elders, "the mura (verdict) to migrate into rainy season grazing lands of Dhas district, such as balale-gugurdo, raaro-fullessa and balale-didiko after the commencement of either ganna or hagayya rain was made by jaarsaa reera and jaarsaa arda." The management at the olla (village) level is given to abba olla to execute the decrees made by jaarsaa dheeda, jaarsaa reera and jaarsaa arda (Figure 3). As consequences, these customary institutions have played an energetic role in managing the delivery and access to pastureland in faithful and equal ways.

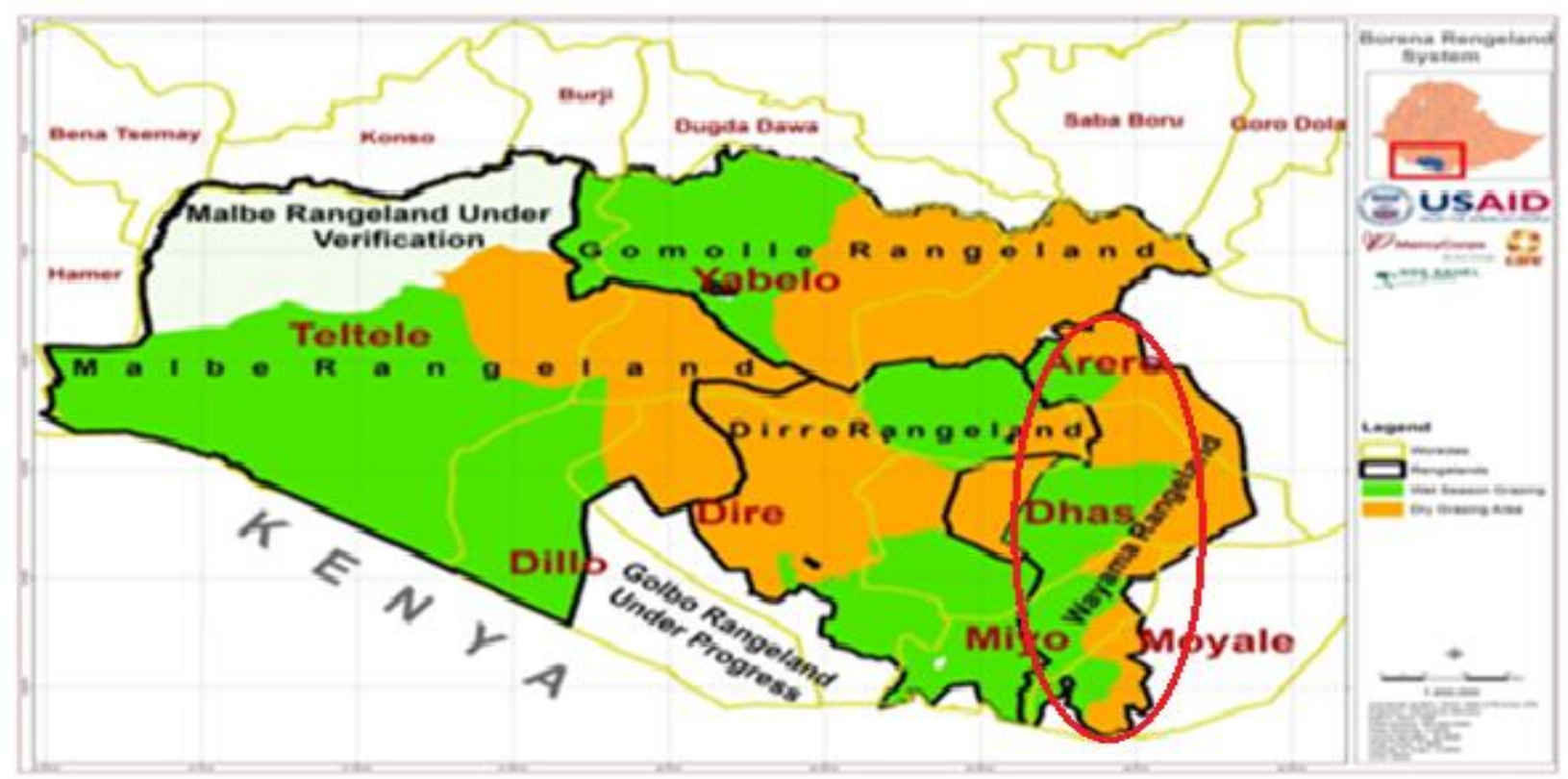

Figure 2: Map showing the geographical location of the five dheeda in Borana zone and Matawayama rangeland unit in Dhas district [Source: Adapted from PRIMA (2015), cited in Abdu and Robinson (2017)]

\footnotetext{
${ }^{2}$ Dheeda is the large cluster of rangeland unit's area for which talented jaarsaa dheeda is designated to manage.

${ }^{3}$ Jaarsaa dheeda is a customary elder that administers rangeland unit.
} 


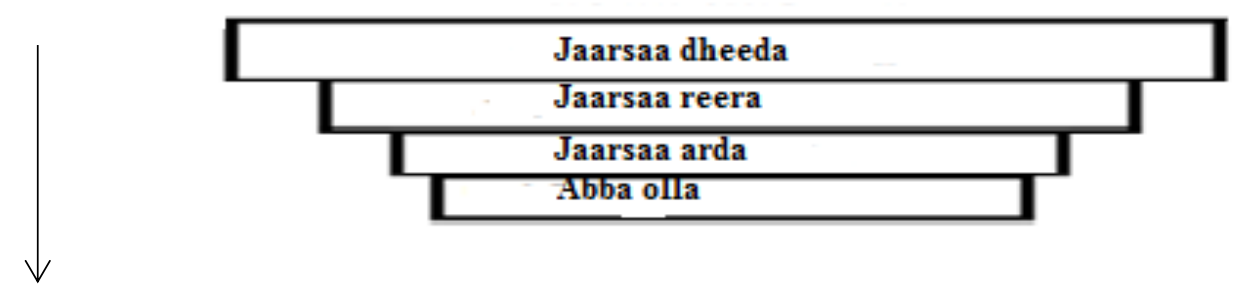

Figure 3: Hierarchies of customary leaders of rangeland management system

Henceforth, governmental organizations and development actors ought to work in partnership with these traditional structures of social capital to grapple the challenges presently encountered by the Borana pastoralists' customary institutions of rangeland management.

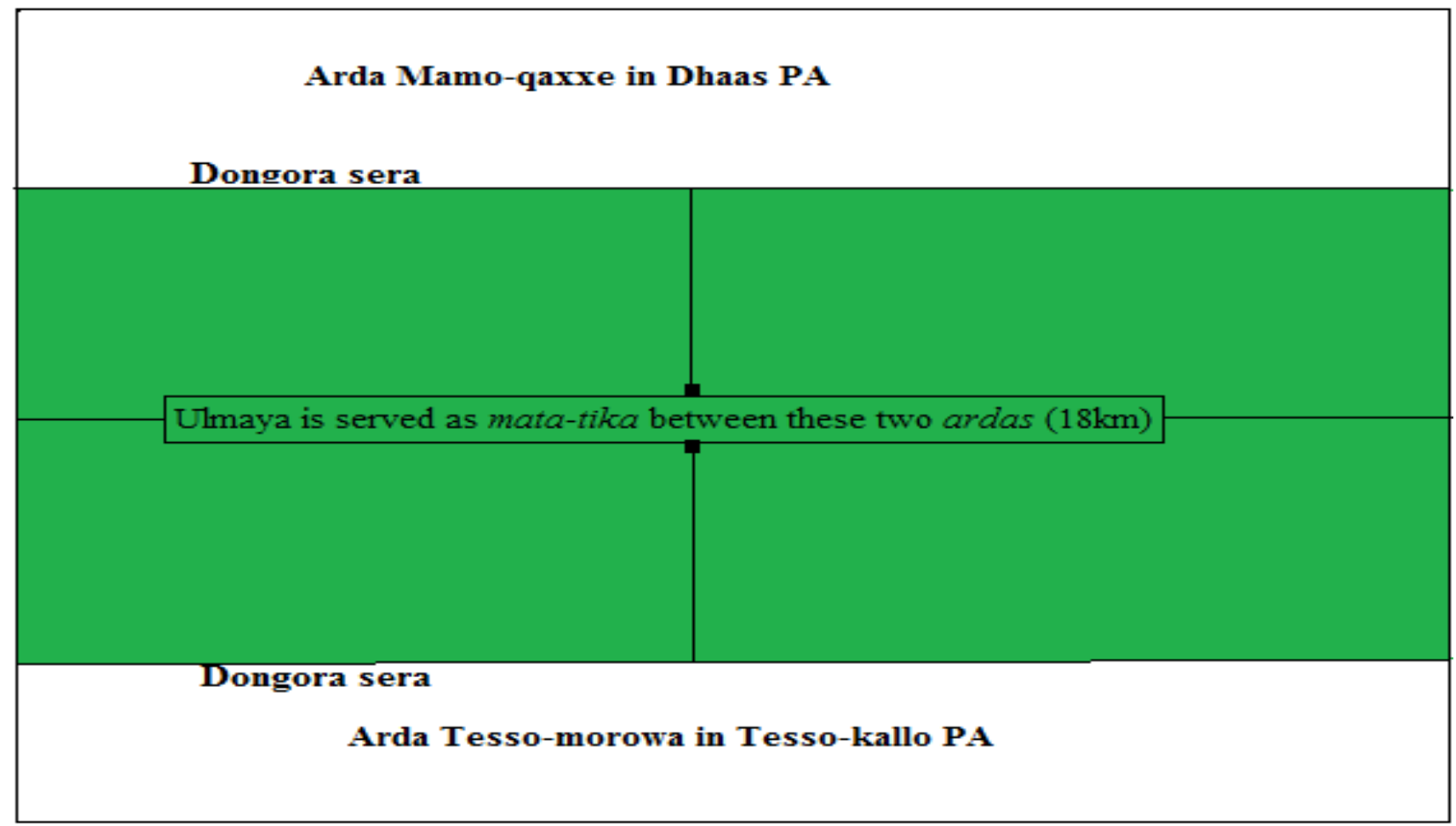

Figure 4: Map showing settlement orders according to customary rule of dongora sera with adjacent arda and mata-tika between arda Tesso-morowa in Tesso-kallo PA and arda Mamo-qaxxe in Dhaas PA

\section{Dongora sera}

The Borana pastoralists have their own customary settlement rule (dongora sera) that obliges every member of the encampment clusters to encamp in straight line with the others; thereby, settlements are in parallel side to the grazing lands (Figure 4). According to this customary settlement rule, no one is endorsed to encamp in dry and wet season grazing reserves and in forward facing of the other fellow villagers. This customary practice is commonly used by Borana pastoralists to save 
pasture for the dire time, to broaden grazing land scope as well as to hinder inflowing of human settlement into the adjoining dry and rainy season grazing land areas.

According to an informant, "each arda has its own mata-tika (grazing parameter) that served as the ultimate boundary between them; through this rehearsal flock of livestock from two different arda reach grazing climax in a diurnal and cannot be side-stepped by cattle keepers from neither of the adjacent encampment clusters." Hence, any cattle keepers who deliberately violated the customary practice of dongora sera would face punishment as per customary rules of rangeland management.

\section{Cattle mobility}

For Borana pastoralists, cattle mobility is one of the utmost accustomed means of getting what livestock need in an erratic environmental situation. They used cattle mobility as strategies for managing scanty rangeland resource in a sustainable way. According to key informants and FGD participants, there are two types of cattle mobility, namely: godansa warra guda and godansa gu'essa. Godansa warra guda is the customary practice of cattle mobility that comprises the migration of entire family and livestock. Customarily, this type of cattle mobility was practised by Borana pastoralists when drought period is too protracted. They would migrate to other areas where abundant pasture and water resources are available. Godansa gu'essa is also the types of cattle mobility which predominantly consists of steers, pregnant cows and dissuaded calves. Livestock habitually migrate with young male herders on the onset of rainy seasons to search water and pastureland. One key informant stated the following, regarding the cattle mobility:

"Usually, we migrate our livestock to Mata-wayama rainy season grazing land areas shortly after the ganna or hagayya rain. In addition, when the bonna (drought) period is extended, we would move our livestock to faraway areas along Golbo rangeland unit (proximate to Ethio-Kenya margin) and Dawa River in Liban district of Guji zone administration to access water and pasture for our drought-stricken livestock."

As a result, the customary practice of mobility-based livestock classification abetted Borana pastoralists to utilize inadequate rangeland and water resources in lafa warra guda and lafa gu'essa more adeptly.

\section{Herd splitting}

Herd splitting was cited by informants as the practice of dividing livestock in accordance with their similarities and pasture preferences. The Borana pastoralists herd flocks of camel and cattle separately, as each of them requires different pastures, environmental adaptation and herding styles (i.e., camels entirely feed on tree leaves and branches, whereas cattle solely prefer grasses). By contrast, small ruminants such as sheep (grazer) and goat (browser) are flocked together. Sporadically, Borana pastoralists keep herds of goat separately in the areas where there is a high prevalence of bush infringement. As goats are dominantly feed on shrubbery leaves; thus, it would help to curtail the incidence of bush incursion.

Typically, the customary practice of herd splitting depends on livestock possession, as it was mostly practiced by households with considerable number of livestock. In some cases, households 
with small herd size shepherd cattle, sheep and goat flocks together. However, they never shepherd camels with other flocks of livestock owing to their inimitable shepherding style and enormity of their corporeal appearance.

\section{Herd diversification}

Herd diversification is the practice of keeping a variety of livestock species to use efficiently the scarce rangeland and water resources, and to withstand the impacts of drought that may distress the productivity of livestock. In addition to cattle, sheep and goat, camels are reared by less than $45 \%$ of the Borana pastoralists in Dhas district. This lower percentage of camel domestication attributed to cultural restriction that denied some clans of Borana pastoralists (such as Karrayubere, Karrayu-manxe, Oditu-ido, Karrayu-badi and Karrayyu-didimtu) to domesticate and consume camel products (meat and milk). However, these clans are currently involved in camel rearing at alarming rate against cultural taboos because of its productivity and adaptation to drought.

Even though camels were not popular among the Borana pastoralists unlike cattle, recurrent drought and its severity had forced them to introduce camel at increasing rate in their herds. A key informant from DDPDO stated that, after the severe drought of 2010/2011, some nongovernmental organizations (NGOs) based in Dhas district distributed camels to drought victims in Borbor, Dhaas and Tesso-kallo PAs with the aim of encouraging camels' domestication in Dhas district. Consequently, the distribution of camels by an NGO, Action for Development (AFD), triggered a surge in the number of camels since 2013. Thus, the massive loss of cattle during the past three decades, which was prompted by extreme drought, encouraged the Borana pastoralists to upsurge the domestication of camels as an alternative advantage owing to its extraordinary ecological adaptations in contrast to other herds, which are exceedingly prone to the impacts of drought.

\section{Bush burning}

The Borana pastoralists traditionally have practised bush burning techniques to boost rangeland productivity, to control thorny bush, to wipe-out ticks and to provide plenty of forage for livestock during the drought period. According to Borana elders, the particular areas of grassland that required to be burnt would be identified through qualified customary leaders. The identified part of the rangeland is scorched late in the evening when there is moderate heat and wind, and rainfall is anticipated soon to elude any opportunity of fire that may spread into adjoining grazing reserves and human settlements. Furthermore, after the identified part of the rangeland is scorched the fire is controlled by kara ibida. Kara ibida is the practice of making paths (roughly 2-3 meter wide) through slashing of grass and trees between proposed grassland for burning, and adjacent villages and rangeland areas to halt the fire from diffusing into proximate villages and grazing lands.

According to informants, Borana pastoralists classify bush burning in to three main categories on the bases of their burning cycles. Three categories are as follows:

$G u b a$ - A particular rangeland area that burned every year. This annually burned grassland has a higher yield in contrast to gursumessa and fura types of bush burning. 
Gursumessa - A burned grass land that functioned only one year after burning and then burned every second year.

Fura - A pastureland which is unburned for long period of growth season. This unburned grassland has lower productivity in contrast to guba and gursumessa which burned annually and every second year, respectively.

Currently, in Dhas district, numerous NGOs have been trying to remove thorny bush covering in all PAs. It is against the Indigenous regulatory methods used to control bushes. In addition, due to cash for work (relief food assistance) members of communities are steadily becoming reluctant to conserve their natural resources by their own interest, unlike previously.

\section{Customary Institutions of Water Management and Utilization Strategies}

\section{Konfi}

The Borana pastoralists have developed the complex varieties of customary institutions to systematically manage the utilization of deep wells and ponds in their localities. A key informant stated that:

"When a particular ella/tulla (deep well) or haro (pond) was excavated, the person who discovered the stream of the ella or haro through the process of ginfessu (digging firstly the supposed deep well stream's area three or four times by hoe as insignia for discoverer) was entitled to the konfi (initiator). He is considered as abba ella (father of the well), and he would administer the day-to-day operation of the ella or haro through abba herrega (manager for daily watering order)."

This right is mainly claimed by the initiator of the deep well as well as those belonging to the clans of the deep well founder. For instance, if the konfi is from Digalu clan of Borana pastoralists, the deep wells also belong to entire Digalu clan. However, key informants and FGD participants confirmed that, as it was a common property for all Borana pastoralists, the ownership of the deep wells is not transmuted into an absolute clan property. As a result, each member of the Borana pastoralists is customarily permitted to let their livestock drink water regardless of their clan's origin. Furthermore, key informants elucidated that "if other ethnic group request water for their cattle based on the customary water rules and regulations ... Borana pastoralists cannot deprive any non-Borana people."

\section{Abba herrega}

The duty of the routine supervision of deep wells and ponds is given to the abba herrega. The selection of abba herrega is primarily based on the avoidance of conflict and his fidelity among the users irrespective of his clan origin and affiliation to deep wells and ponds initiators. According to customary elders, deep wells serve its customers based on customary practice of elli qara fi ege qaba (deep wells have first and last served) utilization rules. Therefore, the rules of access to the deep wells are determined by sadden (watering cattle every three days). To use the water, guyya qara (the first day) priority is given to konfi (on guyya qara no livestock can drink before konfi's livestock drinks); and then guyya lamesso (the second day) priority is given to abba herrega. The 
guyya sadesso (the third day) is for mandhicha (seniority based on age among the konfi clan members), thus eldest person's cattle are permitted to drink before any queued cattle on third day.

However, unlike the rules of access to the deep wells, the access to ponds is not managed through the customary rules of sadden. In the instance of ponds, konfi is not entitled to claim ownership right over pond. As a result, the utilization of ponds is not founded on the priority distribution of water, unlike the deep wells where first three days priority is given to konfi, abba herrega and mandhicha, respectively, based on the customary rules of sadden. The other unique feature, that distinguishes the utilization of ponds from that of deep wells, is called meri. Meri is a slim tree branch that is used to hinder cattle from directly entering a watercourse (Figure 5). However, in case of the deep wells there is no meri, instead they depend on the naniga (tiny trough) to drink the cattle. Therefore, water hauled from the deep wells through totu (hierarchies of water haulers) firstly into facana (wider trough) and then into naniga, serving the livestock directly (Figure 6). Furthermore, to ensure the sustainable utilization of deep wells and ponds, every user has a duty to clean its compound as well as water troughs on regular basis prior to drinking their livestock.

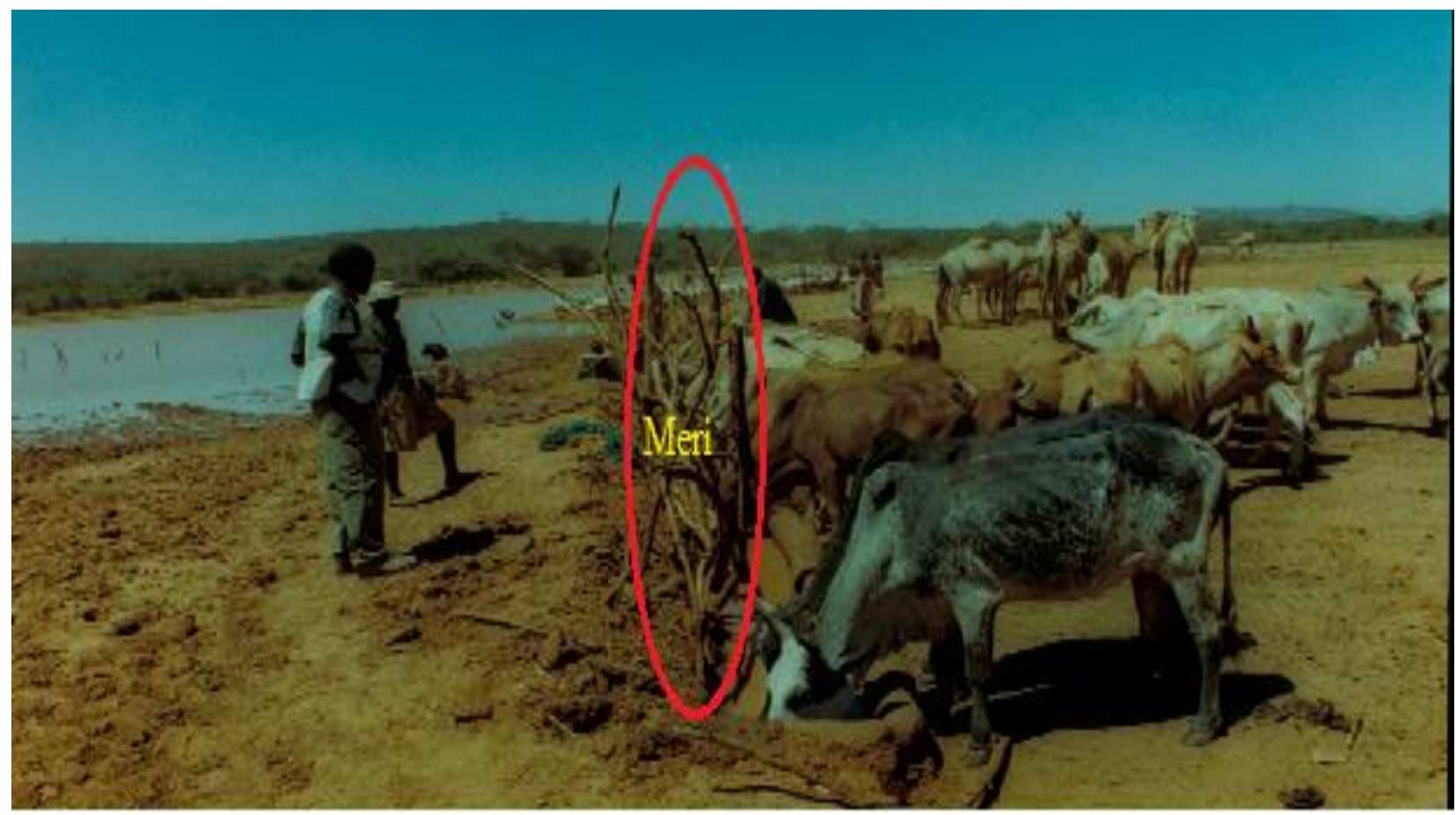

Figure 5: Showing meri and synchronized access to water at a pond [Source: Homann (2004) and slightly modified by author]

\section{Indigenous Environmental Knowledge of Floras and Faunas Relations and Their Uses}

The Borana pastoralists have an immense knowledge of diverse flora and fauna species in their milieu. They have classified the flora species according to their ecological connections, such as flora-fauna relations, soil assortments, topographical dwellings, and sustenance values. The florafauna relations are conveyed through the joint designations of both flora and fauna that signify the plant species as well as the animal foraging on that plant species. For instance, agagaro harree 
(Barleria argentea) is a name given to plant species that is named after donkey displaying its utmost choice for this forage plants. Similarly, xaxessa and ogora gaala (Premna schimperi and Capparis tomentosa) were forage plant species that were named after camel and typically favoured by the camels. Moreover, the local designations of some floras describe their prominence. For instance, abrasa looni (cattle's abrasa) is a name given to aloe flowers showing that their flowers are annually placed on both sides of the cattle pen entrance (from late February to March) as a signal of transition from drought season to the onset of rainy season of ganna. Hamarressa (Acacia brevispica) is also a tree species that is mostly preferred by camels and its leaf is used to heal the wounds of both humans and animals.

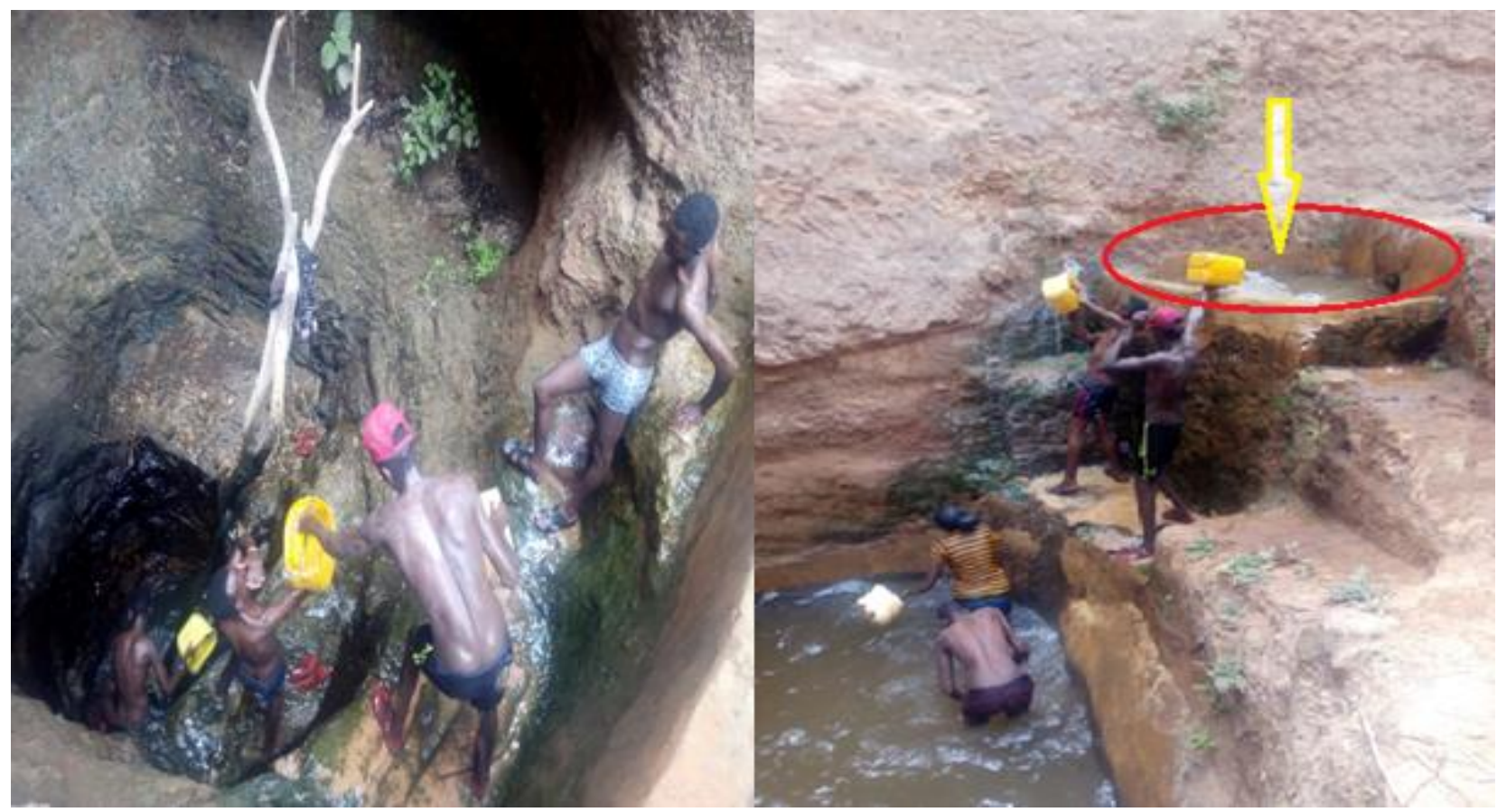

Figure 6: Watering procedure at deep wells in Gayo PA: (a) a totu towing water from the stream of Dirbu deep wells (left side) and (b) facana (wider trough) of Nonnicha deep wells (right side)

\section{The Perception of Local Communities on Indigenous Environmental Knowledge}

The Borana pastoralists have their own IEK of water and rangeland management. The customary management of rangeland and water resources and its utilization strategies were acquired by local communities through daily personal interactions beginning from childhood when they play with their companions and shepherd cattle. As per key informants and FGD participants' views, "the local communities have knowledge of customary rangeland and water management and its utilization strategies." However, the nature of the perceptions is not identical across all members of the communities. Some informants commonly articulated that:

"Youth perceptions on the IEK are not wide-ranging in contrast to adult and elder members of the communities owing to numerous youth enrolment into modern education and the introduction of alien technologies into customary NRM of Borana pastoralists at frightening rate. Such factors have contributed for dissimilarities in perceptions. Hence, community 
members progressively continue to disobey and swap IEK and customary rules with the modern systems."

In addition, a key informant stated that "transformation in the utilizations of IEK was founded upon intended determinations by members of the local community to seek solutions to their existing problems through local trial and error methods." Conversely, there are some kinds of perceptions in which the skill of undertaking is always kept secret from local communities and is uttered merely to the family of the experts or nearest relatives. This secret transfer of expertise is highly observed among ciressa (traditional healer) and traditional weather forecaster. However, informants commonly stated that "the sustainability of the IEK of Borana pastoralists is doubtful, as it is transferred from one generation to another through the words of mouth, while exclusively depending on customary leaders." As a result, it is worthwhile to develop collaborative mechanisms by involving all relevant stakeholders to document and propagate the existing IEK of Borana pastoralists to ensure their functionality and sustainability.

\section{The Role of Social Capital in Natural Resources Management}

The Borana pastoralists have hierarchies of traditional NRM structures that integrate the customary rules and regulations to ensure the sustainable management and impartial accessibility of the rangeland and water resources to all peoples. The maintenances of such customary rulings are executed by customary leaders of water and rangeland resources. For instance, dheeda is the single largest portion of rangeland segmentation that is managed through jaarsaa dheeda. As discussed in preceding section, jaarsaa dheeda has the authority to supervise the proper utilization of rangeland unit as well as schemes of cattle mobility. Jaarsaa madda is also the customary leader who manages areas related to permanent deep wells that structured according to imminence of water-stream clusters. Congruently, Abba herrega is liable for daily utilization of drinking mandate and monitoring mismanagement of water resources. As a result, when any members of the communities despoiled the customary rules of water and rangeland management, these customary leaders have the authority to punish the offenders as per the Borana pastoralists' customary laws of rangeland and water resources management. For instance, when members of the communities defy the customary utilization of water and rangeland management, customary elders would apply the following sentences: persons that violated customary management of rangeland (reared livestock in restricted areas) would be penalized from 1-5 cattle depending on the gravity of offender's offense. Similarly, any person who does not partake in maintaining deep well and pond water trough and clean its compound prior to drinking his livestock is either deprived of access to or forced to fence the compound of such water resources.

Pastoralists in the study district confirmed that the effectiveness `of customary NRM is founded on the endowments of customary leaders to resolve quarrels as well as enforcing verdicts on offenders that desecrated the customary management of rangeland and water resources. Accordingly, when conflict materialized between two individuals or adjacent encampments on the utilization of forage and water resources, jaarsaa reera, jaarsaa arda, abba olla and other relevant customary elders impartially arbitrate on the cases of disputants to find long lasting solution to existed problems. However, the cases would transfer to Abba Gada (the customary leader for the entire Borana pastoralists) if the parties in conflict rebuff to accept the decrees of customary leaders at the lower levels of management. As Abba Gada has the ultimate authority to judge on all unresolved disputes, 
and offenders would have to accept $A b b a$ Gada's final decree whether they are gratified or not by that.

Thus, the multi-dimensional structure of customary institutions by which the Borana pastoralists govern their pastureland and water resources are based on the ladders of customary authorities of Abba Gada, jaarsaa dheeda, jaarsaa reera, jaarsaa ardaa and abba olla. Accordingly, these customary leaders become the custodians of Borana pastoralists' natural resources through punishing the offenders and imposing public margins that protect rangeland and water resources. The study considers that capitalizing on these social capitals of NRM will upsurge the solidarity amongst customary leaders, local communities, and development actors.

\section{Challenges Faced by Indigenous Environmental Knowledge of Borana Pastoralists}

According to the informants, the foremost challenges that were encountered by the IEK of Borana pastoralists in Dhas district are mentioned as follows:

\section{Perennial Conflict over Boundary and Grazing Areas}

According to Borana pastoralists, unresolved boundary entitlements with Garri Somali was intensified following the regional boundary demarcation and referendum, which was held in 2005. It triggered Borana pastoralists to lose their rainy season grazing land areas. Moreover, key informant substantiated that:

"When we migrated from our rainy season grazing land areas of the eastern Mata-wayama rangeland ephemeral areas, such as boji, dhaka-wata, cari-ilu, dida har-heddu, tuma, udet and kojiya to our dry season grazing land areas around the traditional deep wells of Gorille, Gayo, Dhaas and Borbor ... Garri people tenaciously encamp on our rainy season grazing lands, thereby, they resisted the return of our herders to their satellite camps."

Recurrent conflict over boundary and the seizure of Borana pastoralists' rainy season rangeland areas have put the residual grazing land under the precarious pressure. Consequently, the IEK and customary institutions have encountered perilous challenges owing to the prevalence of conflicts, alienation of rainy season transitory areas, and the environmental degradations that happened because of reduction in rangeland assets.

\section{Environmental Degradation}

Nowadays, the prime challenges for the IEK of Borana pastoralists are the alienation of rainy season rangeland areas, perpetual conflicts, increasing number of livestock and human population have furthered pressure on the earlier degraded environments. According to informants and field observations, there is evidence that environmental degradation interrupted the configuration of cattle mobility through thinning lafa warra guda and lafa gu'essa pastureland areas. Consequently, unceasing environmental degradation had accelerated the deterioration of the IEK of Borana pastoralists in addition to various internal and external intrusions that undermined their practicality. 


\section{Drought}

In Dhas district, perennial drought has created substantial threats for the sustainability of the IEK of Borana pastoralists. Previously, Borana pastoralists were capable to deal with drought impacts as they were customarily accomplished to migrate to new productive grassland areas. Nonetheless, discussions with key informants and FGD participants indicated that "in the past two decades recurrent drought resulted in perilous environmental degradation and livestock fatalities owing to drought cycles condensation from 10-12 years to 3-4 years." Moreover, the partial annexations of Mata-wayama rangeland has weakened the customary NRM of Borana pastoralists to cope with the impacts of drought through cattle mobility, and thus exposed them to confine in very limited areas.

\section{Population Pressure}

The customary practice of rangeland management comes under pressure when human population increases. Nevertheless, informants commonly cited that the hasty growth of human populace has triggered detrimental consequences for the IEK of Borana pastoralists. For that reason, currently in Dhas district under the continuously burgeoning population pressure, the distance between two adjacent groups of villages is progressively shrinking due to unprecedented population growth. It inflicted the Borana pastoralists to encamp in the formerly circumscribed dry and rainy season rangeland areas. Hence, the challenges to the IEK of Borana pastoralists are accelerated, consequently.

\section{Weakening of Customary Institutions}

The customary institutions of Borana pastoralists are constituted on leadership schemes that govern the daily management and utilization of rangeland and water resources. However, informants reported that:

"Nowadays, the power of our customary leaders and NRM institutions are deteriorating. Even though we used the customary rules to manage our grazing land and water resources for centuries, government proposed institutions, bans on customary practices (i.e., bans on bush burning) and unfitting external interventions have intensely paved the way for steadily decaying of our customary institutions than ever before."

This study signposted that both governmental and NGOs originate with top-down development approaches that have progressively weakened the Borana pastoralists' customary leaders' authority, customary institutions and its utilization strategies.

\section{Decay of Dry and Wet Season Grazing Reserves}

The customary practice of keeping grazing reserves in lafa warra guda and lafa gu'essa by the Borana pastoralists of Dhas district was centred on the seasonal livestock mobility patterns. However, currently, the tradition of keeping dry and wet season grazing reserves is coming under potent pressure and steadfastly abridging in Dhas district due to the diminution of grazing reserves of both lactating and non-lactating livestock. It is triggered by environmental degradation, rangeland alienation, thorny bush invasion, drought, and population growth. 


\section{Bush Invasion}

Traditionally, Borana pastoralists practiced rotational burning of rangeland areas as a mechanism to regulate undesirable grass species, to refurbish pastures and to confiscate unpalatable thorny bush species. Though, the rapid incursion of thorny bush species that never have a merit to the livestock has generated detrimental trends for the environmental productivity and sustainability of Borana pastoralists' rangeland in Dhas district (Figure 7). The participants of the study revealed that the leading reason for bush invasion on the rangelands of Borana pastoralists nowadays is an erroneous government ban of the traditional bush burning practice.

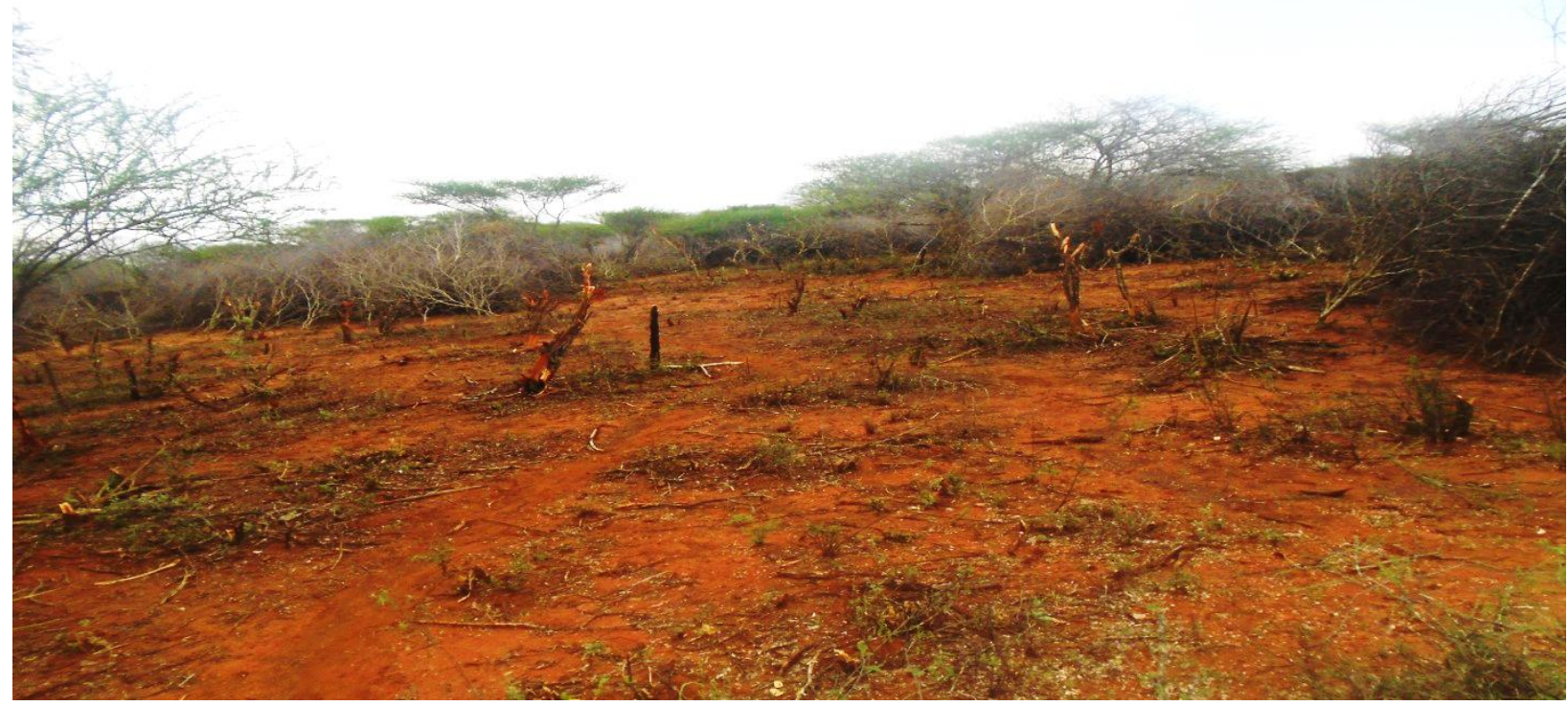

Figure 7: The condition of thorny bush invasion at arda Kobe in Gorille PA [Source: DDPDO (2019)]

Accordingly, this restriction of bush burning practice for the last three consecutive decades has intensified the disruption of the Borana pastoralists' traditional natural resource governance system in conjunction with unceasing environmental degradation, recurrent drought and conflict, etc. in all PAs of Dhas district.

\section{Discussion}

The sustainable use of IEK, notably at local level, is vital for mobilizing natural resources and regulating their utilizations to sustain a robust base for productive activities of natural milieus (Uphoff, 1992). The IEK of pastoralists has been shown to be enormously effective in the sustainable utilization of natural resources. Instituting on IEK, Borana pastoralists classified the rangelands based on two factors: season of utility and grazing dimensions (i.e., grazing land for calves, lactating and non-lactating livestock, etc.). The findings of this study confirm that the taxonomy of rangelands with diverse functional land use segmentation is attained through concurrence among the customary leaders and communities. It is in consistence with the findings of (Homann, 2004; Dalle, Johannes and Brigitte, 2006; Beyene et al., 2016). This study indicates 
that Borana pastoralists have practiced varieties of Indigenous regulatory methods (i.e., cattle mobility, settlement directive, herd diversification, range scouts and herd splitting) to reduce the grazing pressure and to cautiously utilize skimpy rangeland and water resources. The study by Khwarae (2006, p.36) is also in line with the results of this study. Given that, for mobile pastoralists, the rangeland is only economically viable when used and managed as a whole. The pastoralists have continued their seasonal movements to access dry and wet season grazing areas and water resources (Pavanello and Levine, 2011, p.3). Moreover, Belayneh (2016) stated that "in addition to seasonal movement of livestock, the Borana pastoralists use supplementary risk controlling strategies. One of such strategy is the controlled burning of grazing areas" (The Social Institutions of Borana Pastoral Community Section, para 4). To affirm this, Gebru et al. (2007), as cited by Musa, Hakim and Mukeram (2016, p.312), attested that:

"An example data set from plots burned at Dida-hara PAs in Arero district of Borana zone, in 2005 , proved that the cover of highly valued grass increased from $18 \%$ to $40 \%$ of the basal cover, and the amount of bare ground was accordingly ... [abridged] after burning."

IEK has developed from experiences in biodiversity conservation and the use of natural resources by local communities with basic principles of sustainable NRM (Lilito, 2010). The studies by Nassef and Belayhun (2012) showed that Ethiopia's Borana pastoralists have the most elegant water and rangeland management systems in east Africa. Customarily, Borana pastoralists managed their pastures and water resources through the hierarchies of territorial divisions of customary leaders of jaarsaa dheeda, jaarsaa madda, jaarsaa reera, jaarsaa arda and abba olla. These findings corroborate with the findings by Boku (2000) and Beyene et al. (2016), which clarified that Gada system (aboriginal system of governance developed from knowledge gained by community over generations) and its customary institutions as a customary natural resource administrative structure administrated through the customary leaders in accordance with the customs and laws of the Borana pastoralists.

Among the Borana pastoralists, water and rangeland are communal property, thus customary leaders impartially manage to verify equivalent utilization and access to the resources for all Borana pastoralists. The foundation for these customary institutional accomplishments in NRM ascends from such customary management "so as to allow for greater participation by local peoples and their customary leaders" (Kioko and Christopher, 2006). Congruently, Nassef and Belayhun (2012) found that among the Afar pastoralists of north-eastern Ethiopia customary leaders usually control over several strategic resources such as seasonal grazing areas and water points. The decisions on access to and control of these natural resources are made by the clan leaders, clan elders and a traditional rule-enforcing unit (Hundie, 2006 cited in Nassef and Belayhun, 2012). Many authors (Boku and Irwin, 2003; Bernabini, 2012; Odhiambo, 2012) have highlighted that Borana pastoralists creatively designed their customary NRM institutions to address environmental constraint through preserving the utilization of commonly shared natural resources. In contrast to the customary institutions of Borana pastoralists, Beyene et al. (2016, p.74) illustrated that:

"[Karrayu] pastoralists are struggling to maintain the Gada system with more simplified structures for and limited role in the use and administration of communal land and rangeland resources. [Even though] ... customary rules and regulations for seasonal grazing, cattle mobility and pasture reserving and use ... still exist [among the Karrayu pastoralists]. [Inversely] ... their role is significantly limited much more than their counterparts in Borana [pastoralists] area (emphasis added)." 
The customary law of NRM ensures public parameters that protect rangeland and water resources through customary leaders to enforce restrictions on the use of deep wells, ponds, and wet and dry season rangeland reserves that might require retrieval. Agrawal (1997, p.31) described that "imposing punishments on those who break rules is predicated on effective metering and monitoring. Sanctions also make monitoring meaningful, since without the threat of sanctions rule breakers would not care whether they were monitored and caught." The punishments for customary lawbreakers would be applied based on the intensity of the offender's offences. Consistently, Edward and Paul (2014) reported that both the Borana and Baringo pastoralists of central Kenya have an elaborate system of fining people who graze their animals on the rangeland reserves without the consent of customary leaders.

Previous studies (Belayneh, 2016; Musa et al., 2016; Abdu and Robinson, 2017) have shown that shrinking of grazing reserves, high population density, frequent drought, shortage of forage resources, bush encroachment, weakening of traditional resource management practice, climate change and bans on traditional fire management, etc. are the main challenges for the IEK of Borana pastoralists and its customary institutions. Therefore, this study and others (Homann, 2004; Beyene et al., 2016) argue that recognizing and cooperating with customary leaders and institutions based on guiding principle of customary laws is essential to promote the IEK of Borana pastoralists. Additionally, in the efforts to refurbish IEK, it is pivotal to respect and apply IEK of pastoralists with their full involvement and collaboration. Hence, the IEK of Borana pastoralists ought to be encouraged and protected by all pertinent stakeholders. By this means, they will withstand any internal and external influences that may jeopardise their practicalities.

\section{Conclusion}

The IEK of Borana pastoralists is linked to the customary NRM including range scouts, herd diversification, categorization of rangeland based on the season of utility and gazing dimensions, herd splitting, bush burning, settlement rules and cattle mobility, and so on. The complex networks of customary institutions by which the Borana pastoralists governed pastureland and water resources have been based on the hierarchies of customary authorities that were responsible for customary management of natural resources. In a view of this fact, IEK is often seen as a communal knowledge, rules, and views about patterns of interaction that aboriginal peoples bring into sustainability. It is concluded that recognizing the IEK of Borana pastoralists is indispensable to ensure their practicalities in justifiable NRM.

Moreover, Dalle, Johannes and Brigitte (2006) argue that the prime threats to the IEK of pastoralists were instigated from disregarding and undermining of pastoralists IEK. For this reason, this study concluded that protecting the IEK of Borana pastoralists and its customary rules will increase the constructive partnership between development actors, local communities and customary management of natural resources and livestock production that will also improve the livelihoods of the Borana pastoralists as well. 


\section{Acknowledgement}

I would like to express my deepest heartfelt gratitude to Mr. Yitebarek Hizkeal (Institute of Indigenous Studies, Dilla University, Ethiopia) for his productive and insightful remarks on this research manuscript.

\section{References}

Abdu, N. and Robinson, L. (2017). Community-based rangeland management in Dirre rangeland unit: Taking Successes in Land Restoration to scale project. ILRI project report. Nairobi, Kenya: International Livestock Research Institute (ILRI).

Agrawal, A. (1997). Community in Conservation: Beyond Enchantment and Disenchantment. CDF Discussion Paper, ISBN 0-9662380-0-1. Conservation \& Development Forum, Gainesville, FL 32611-5531, USA.

Arjjumend, H. and Beaulieu-Boon, H. (2018). Customary Institutions and Rules underlying Conservation Functions of Sacred Sites or Indigenous and Community Conserved Areas. Grassroots Journal of Natural Resources, 1(2): 1-12. Doi: https://doi.org/10.33002/nr2581. 6853.01021.

Arjjumend, H., Konstantia, K., Fagan, H.G. and Shibata, S. (2018). International Overview of Sacred Sites and Indigenous and Community Conserved Areas (ICCAs) and the Need for Their Recognition. Global Environmental Studies, 13: 33-56. Online: http://digitalarchives.sophia.ac.jp/repository/view/repository/20180703003.

Ayalew, G. (2004). The effect of development projects on the Karrayu in Metahara area. In: People, space and the state. Migration, resettlement and displacement in Ethiopia. Proceedings of workshop held by the Ethiopian society sociologist, social workers and Anthropologist. Addis Ababa: Bole Printing Enterprise.

Belayneh, D. (2016). State Development Interventions versus Indigenous Resource management institutions: Whose Reality Count? Evidence from Borana Pastoral system of southern Ethiopia. Online: https://mpra.ub.uni-muenchen.de/70780/.

Bernabini, F. (2012). Pastoral livelihoods in South Ethiopia-Value chain assessment of gum and resins in Moyale area. Dissertation thesis, Alma Mater Studiorum Università di Bologna. Dottorato di ricerca in Cooperazione internazionale e politiche per lo sviluppo sostenibile, 24 Ciclo. Doi: http://doi.org/10.6092/unibo/amsdottorato/4996.

Bernard, H. (1995). Research Methods in Anthropology, Second Edition. London: Sage Publications.

Beyene, F., Boku, T., Gadissa, T., Jabessa, T. and Medhanit, A. (2016). Assessment of the Customary Land Administration and Natural Resource Management in the Pastoral Areas of the Oromia Regional State. Addis Ababa: Ethiopia Institute of Agriculture Research. Online: http://hdl.handle.net/123456789/2719

Boku, T. (2000). Individualizing the Commons: Changing resource tenure among the Borana Oromo of southern Ethiopia. MA Thesis submitted to the School of Graduate Studies, Addis Ababa University.

Boku, T. and Irwin, B. (2003). Traditional institutions, multiple stakeholders and modern perspectives in common property. Accompanying change within Borana pastoral systems. London: IIED. Online: https://pubs.iied.org/9238IIED/?s=STC 
Braun, V. and Clarke, V. (2006). Using thematic analysis in psychology. Qualitative Research in Psychology, 3: 77-101.

Coppock, D.L. (1994). The Borana plateau of southern Ethiopia: synthesis of Pastoral research development and changes, 1980-90. International Livestock Centre for Africa.

Dalle, G. (2004). Vegetation ecology, rangeland condition and forage resources evaluation in the Borana Lowlands, Southern Oromia, Ethiopia. PhD Thesis, University of Gottingen, Germany.

Dalle, G., Johannes, I. and Brigitte, L. (2006). Indigenous ecological knowledge of Borana pastoralists in southern Ethiopia and current challenges. Institute for Crop and Animal Production in the Tropics, Georg-August-University Göttingen, Germany.

DDPDO (2019). Annual Report. Borbor, Dhas, Ethiopia.

Denge, G. (2011). Coping with scarcity in Northern Kenya: The Role of Pastoralist Borana Gada Indigenous Justice Institutions in Conflicts Prevention and Resolutions for Range Resources Managements. MA Thesis, Graduate School of Development Studies, International Institute of Social Studies, The Hague, Netherlands.

Douglas, N. (2002). Indigenous knowledge, peoples and sustainable practice. Social and economic dimensions of global environmental change, vol. 5, pp.314-324. In: Peter Timmerman (ed.), Encyclopedia of Global Environmental Change, Chichester: John Wiley \& Sons Ltd.

Edward, W. and Paul, M. (2014). An Evaluation of Climate Change Indigenous Coping and Adaptation Strategies for Sustainable Agro-Pastoral Based Livelihoods in Baringo County, Kenya. IOSR Journal of Environmental Science, Toxicology and Food Technology, 8(8): 3858.

Ellen, R., Peter, P. and Alan, B. (2005). Indigenous Environmental Knowledge and its Transformations. In: Roy Ellen, Peter Parkes and Alan Bicker (eds.), Critical Anthropological Perspectives. Taylor \& Francis (ISBN 0-203-47956-4 Master eBook)

Gebru, M., Remans, R., Brouwer, I., Baye, K., Melesse, M. B., Covic, N. and Vandenberg, M. (2018). Food Systems for Healthier Diets in Ethiopia: Toward a Research Agenda. IFPRI Discussion Paper Series No. 01720. Washington, DC: IFPRI.

Khwarae, G.M. (2006). Community perceptions of rangeland degradation and management systems in Loologane and Shadishadi, Kweneng North, Botswana. Masters Thesis, Department of International Environment and Development Studies (Noragric) Norwegian University of Life Sciences Universitetet for Miljø- og biovitenskap (UMB).

Helland, J. (2006). Pastoral Land Tenure in Ethiopia. Colloque international 'Les frontières de la question foncière - At the frontier of land issues'. Montpellier. Online: https://www.mpl.ird.fr/colloque_foncier/Communications/PDF/Helland.pdf

Homann, S. (2004). Indigenous knowledge of Borana pastoralists in natural resource management: a case study from southern Ethiopia'. Justus Liebig University Giessen, Germany, Doctoral Dissertation.

ILO (No.169) (1989). Convention on Indigenous and Tribal Peoples. A manual. Geneva: International Labour Office.

Kioko, M. and Christopher, B. (2006). Decentralization of pastoral resources management and its effects on environmental degradation and poverty Experience from northern Kenya. World Vision Canada and Cornell University. Online: http://barrett.dyson.cornell.edu/Parima/Papers\%20from\%20Cbb2/Papers/MunyaoBarrett\%20October\%202006.pdf 
Lilito, D. (2010). Indigenous knowledge and practices of tribal groups on community-based forest management program: Institute of Agroforestry and Watershed Management Don Mariano Marcos Memorial State University Bacnotan, La Union. NLR Journal, 3-4.

Mehdi, H., Azarnivand, A., Mehrabi, M., Jafari, H., Nayebi and K. Seeland. (2013). The role of indigenous ecological knowledge in managing rangelands sustainably in northern Iran. Ecology and Society, 18(2): 31. Doi: http://dx.doi.org/10.5751/ES-05414-180215.

Mishra, L. (2016). Focus Group Discussion in Qualitative Research. TechnoLEARN, Vol. 6: No. 1: p. 1-5.

Musa, M., Hakim, H. and Mukeram, T. (2016). Rangeland Degradation: Extent, Impacts, and Alternative Restoration Techniques in the Rangelands of Ethiopia. Madda Walabu University, Department of Animal and Range Science, Bale-Robe.

Nassef, M. and Belayhun, M. (2012). Water Development in Ethiopia's Pastoral Areas. A synthesis of existing knowledge and experience. Save the Children, USA and Overseas Development Institute, UK.

Oba, G. and Kotile, D.G. (2001). Assessments of landscape level degradation in southern Ethiopia: Pastoralists versus ecologists. Land Degradation and Development, 12: 461-475.

Odhiambo, M. (2012). Impact of Conflict on Pastoral Communities' Resilience in the Horn of Africa: Case Studies from Ethiopia, Kenya and Uganda. FAO Report, Nakuru, Kenya.

Pavanello, S. and Levine, S. (2011). Natural resources management in Kenya-Ethiopia border areas. HPG Working Paper.

PRIMA (2015). Principles and Practice of Multi-Agent Systems. Online: http://www.primaconference.org/conferences/prima2015/xwiki/bin/view/PRIMA2015/index.html

Uphoff, N. (1992). Local institutions and participation for development. IIED Gatekeeper series 31. Ithaca, NY, USA.

Zerihun, D. (2005). Indigenous Knowledge, the Environment and Natural Resource Management: The Adverse Impacts of Development Interventions. Debub University, Hawassa, Ethiopia. 